\title{
Harry Potter: Konsumsi dan Pemujaan Komoditas Dunia Sihir (Kajian Media dalam Perspektif Marxis)
}

\author{
Ruth Mei Ulina Malau \\ (ruthmeimalau@gmail.com) \\ (Dosen Ilmu Komunikasi Universitas Semarang)
}

\begin{abstract}
Harry Potter, the book and film series are form of celebration of the magic world commodities. Media then took place as an amplifier that bringing the magic worlds as a part embodied in our real world. Magic commodity consumption turns out with a magically success. Youth in different parts of world named themself as the generation of Harry Potter. The existance of Harry Potter has become a fetishism consumption, but activated so many Marxism critique about inequality and materialism, while consuming and celebrating the cultural industry of Harry Potter.
\end{abstract}

Keywords: Harry Potter, Kajian media, Perspektif Marxism

\section{PENDAHULUAN}

Hogwarts. Nama ini mengacu pada sekolah sihir fiksional yang menjadi setting utama dalam kisah fenomenal J.K. Rowling "'Harry Potter, the Series". Hogwarts merupakan tempat di mana hampir setiap chapter dan scene dalam buku dan film Harry Potter terjadi. Hogwarts memperkenalkan Harry pada dunia sihir (magical world), mempertemukannya dengan dua sahabatnya-Ron dan Hermione, serta membawanya ke dalam berbagai petualangan sihir melawan sang penyihir hitam yang telah membunuh orang tuanya, Lord Voldemort. Hogwarts, adalah tempat sang penulis, J.K. Rowling, melahirkan hampir setiap karakter yang ada di dalam kisah Harry Potter. Dengan kata lain, Hogwarts adalah asal titik awal mulainya kehidupan dunia magis Harry Potter, dan menjadikannya sebagai salah satu kisah paling fenomenal di dunia-mengalahkan kisah dunia fantasi 'Narnia' atau dongeng sejarah 'The Lord of the Rings', yang dulu disebut sebagai the greatest book of the twentieth century dan dianggap tidak ada buku lain yang melebihi popularitasnya.

Kisah fenomenal tentang Harry Potter terwujud dalam sebuah kalimat yang ditemukan penulis dalam situs Twitter yang berbunyi, "1.090.739 words. 3363 pages. 199 chapters. 17 hours \& 13 minutes. 8 movies. 7 books. 1 legend. Thank you J.K.Rowling," . Singkatnya, legenda Harry Potter ini terdiri dari tujuh buku $^{\text {ii }}$ dan dibagi menjadi delapan film ${ }^{i i i}$. Buku Harry Potter telah terjual lebih dari 400 juta copy di seluruh dunia dan juga mensukseskan film adaptasinya yang diproduksi oleh Warner Bros. yang kini mendapatkan hak ijin produksi lebih dari 400 produk terkait Harry Potter (termasuk iPod). Brand Harry Potter diperkirakan bernilai sebesar US\$15 triliun (http://en.wikipedia.org/wiki/Harry_

Potter).

Sebagai sebuah produk kontemporer, Harry Potter benar-benar menorehkan berbagai sejarah. Kisah Harry Potter menarik perhatian dunia sastra dengan diterbitkan berbagai buku-buku terkait dengan apa yang dikisahkan dalam novel tersebut, misalnya "J.K. Rowlings: The Wizard Behind Harry Potter, Unauthorized Biography by Marc Shapiro" (2000), "Fantastic Beasts and Where to Find Them", "Quidditch Through the Ages", "The Tales of Beedle the Bard", dan sebagainya. Penelitian mengenai 
Harry Potter pun banyak dikaji dari berbagai disiplin ilmu. Buku Harry Potter diterjemahkan ke dalam sedikitnya 67 bahasa di seluruh dunia, bahkan yang lebih unik lagi, istilah muggle-yang dipopulerkan oleh Harry Potter untuk mengistilahkan keturunan non-penyihirmenjadi salah satu kata budaya kontemporer yang tercantum dalam Oxford English Dictionary.

Harry Potter membawa pengaruh kultural yang luar biasa dan melahirkan berbagai kelompok fandom di berbagai negara. Harry Potter juga memunculkan berbagai pergerakan sosial, salah satunya adalah kemunculan International Quidditch Association (ICA), yang memiliki visi untuk mendorong diberlakukannya Quidditch (olahraga sihir di Hogwarts) sebagai salah satu cabang olahraga yang nyata. pengaruh yang luar biasa dari Harry Potter ini mengakibatkan baik buku maupun film Harry Potter memperoleh berbagai award dan penghargaan, seperti: 4 Whitaker Platinum Book Awards (2001), 3 Nestle Smarties Book Prizes (1997-1999), the WHSmith book of the Year (2006), Hugo Award for Best Novel (2000), dan sebagainya.

Sebagai sebuah produk budaya kontemporer, Harry Potter merupakan konsumsi massa yang menjual berbagai bentuk komoditas yang melekat di dalamnya. Popularitas Harry Potter merupakan sebuah prestasi dari ekspansi kapitalisme yang menurut Marx, 'The bourgeoisie', has through its exploitation of the world market given a cosmopolitan character to production and consumption in every country' (Elliot, 2009:18). Kaum bourjuis di sini dimaknai sebagai para pemegang kapital (dalam hal ini adalah konglomerat media AOL-Time Warner), yang memonopoli penjualan hampir semua produk Harry Potter. Dengan melirik kesuksesan penjualan buku serinya, AOL_-Time Warner melalui Warner Bros-nya mengeksploitasi karakter Harry Potter dan karakter-karakter dunia sihir lainnya, selanjutnya memproduksi dan mereproduksi berbagai komoditas Harry Potter untuk dikonsumsi secara universal.

Inilah salah satu implikasi dari apa yang disebutkan Theodor Adorno dan Max Horkheimer sebagai 'industri budaya'. Industri budaya ini mengacu pada operasi kolektif media (berbagai bentuk media terkait produk Harry Potter, mis. buku, film, iklan, mp3, dsb) yang memposisikan media sebagai amplifier yang semakin memperluas pengaruh sihir dalam dunia real yang konon memanfaatkan segala hal yang dimungkinkan untuk dikonsumsi sebagai hiburan. Harry Potter, seperti yang diungkapkan Waetjen dan Gibson, sedang membawa dunia modern saat ini untuk merayakan the "magic" of commodity consumption.

\section{PEMBAHASAN}

Harry Potter melahirkan sebuah generasi, yang selama 14 tahun (1997-2011, sejak buku pertama Harry Potter diterbitkan hingga sekuel terakhir film Harry Potter rilis) tumbuh besar bersama dengan kisah fenomenal ini. Di sisi lain, Harry Pottersang penyihir tersebut membesarkan nama penulis J.K. Rowling dan AOL-Time Warner selaku pemegang hak atas sekuel film Harry Potter dan juga merchandisenya.

Sembari memproduksi kapital, Harry Potter memproduksi generasi yang dengan setia mengkonsumsi setiap seri buku dan film terbaru dari Harry Potter dan menangis ketika berpisah dengan produk sekuel terakhir film Harry Potter. Kisahnya menciptakan sebuah pasar universal dalam 67 bahasa di dunia, baik dunia nyata maupun digital. Anehnya, Harry Potter tidak hanya sekedar jualan buku, film, dan merchandise lainnya. Harry Potter adalah sebuah pasar magic yang menjual segala sesuatu yang berkaitan dengan sihir dalam berbagai bentuk komoditas. Sihir, yang selama ini menjadi sebuah dunia yang sangat jauh berbeda dengan dunia kita, kini menjadi dunia yang berhimpitan dengan kehadiran Harry Potter. Harry Potter menawarkan 
cerita tentang bagaimana sihir menjadi sebuah realitas yang tanpa disadari ada di tengah-tengah kita. Sejalan dengan hal ini, J.K. Rowling, ikut menyisipkan berbagai penggalan sejarah-sejarah dunia dan juga mitos-mitos dari berbagai bangsa. Di samping itu, Rowling juga menyisipkan berbagai hal terkait dengan isu-isu sosial dan moralitas yang sering kita temui di dunia nyata.

Rangkaian komodifikasi sejarah dan mitos ini melengkapi proses produksi komoditas dunia sihir Harry Potter, dan menciptakan konsumsi massa terhadapnya. Yang menjadi permasalahan dalam tulisan ini adalah, bagaimana mitos dan sejarah ditransformasikan ke dalam bentuk teks media berupa buku dan film Harry Potter, dan menjadikannya sebuah industri yang disebut Adorno dan Horkheimer sebagai 'industri budaya' yang mencampuradukkan keberadaan sihir dengan dunia real. Sang penyihir Harry Potter, adalah ikon budaya yang produksi dan reproduksinya tentunya menghasilkan berbagai perilaku dan kebiasaan yang telah ditentukan oleh media, yang bagi Herbert Marcuse, media massa dalam hal ini dianggap memproduksi kesadaran yang salah.

\subsection{Industri Budaya Harry Potter, Sebuah Konsumsi Dunia Sihir}

Dalam esai berjudul The Culture Industry: Enlightment as mass deception, Horkheimer dan Adorno menjelaskan bahwa industri budaya menawarkan sebuah gambaran .... a society that has lost its capacity to nourish true freedom and individuality - as well as the ability to represent the real conditions of existence (Adorno dan Horkheimer, 1993:31). Bagi Adorno dan Horkheimer, industri budaya modern memproduksi kenyamanan, dan produk yang terstandarisasi oleh kepentingan murni dari golongan kapitalis. Dalam hal ini, segala bentuk film, iklan, musik, dan bentuk-bentuk industri budaya lainnya, ditujukan untuk kepentingan hiburan yang menghasilkan kapital.
Adorno dan Horkheimer merupakan pewaris terpenting tradisi Marxis yang memperkenalkan gagasan bahwa budaya kontemporer adalah sebuah "industri budaya", yang merupakan karya kunci dalam pendekatan Marxis untuk kajian budaya. Sebagai seorang Marxis yang penuh komitmen, Adorno dan Horkheimer meyakini bahwa bisnis-bisnis besar yang mengontrol pesan-pesan media memiliki kepentingan ideologis. Di dalam paradigma Marxis, media dipelajari melalui metode-metode materialis/historis, biasanya dengan memperlihatkan kekuasaan ekonomi dan ideologi kelas yang berkuasa (Stokes, 2003 :116).

Harry Potter adalah industri budaya, yang menawarkan produk budaya kontemporer berisi sebuah dunia sihir yang dulunya terpisah jauh dari realitas yang ada di dunia nyata. Keberadaan Harry Potter sebagai produk industri budaya menjadikannya sebagai objek konsumerisme dunia sihir, yang pada akhirnya berlanjut menjadi sebuah bentuk fetisisme komoditas. Fetisisme komoditas (commodity fetishism) merupakan konsep pertama yang diperkenalkan Marx dalam The Capital. Dalam buku berjudul Hipersemiotika: Tafsir Cultural Studies atas Matinya Makna, Yasraf Amir Piliang (2003:291-292) menjelaskan bahwa fetisisme (fetishism) adalah sebuah kondisi, yang di dalamnya sebuah objek mempunyai makna yang tidak sesuai dengan realitas objek itu yang sesungguhnya. Istilah fetish sendiri berasal dari bahasa Portugis feitico, yang berarti pesona, daya pikat, atau sihir. Marx menggunakan istilah ini untuk menjelaskan segala sesuatu yang dipuja tanpa menggunakan akal sehat. Fetisisme komoditas adalah sebuah fenomena, yang di dalamnya seseorang melihat makna sesuatu sebagai bagian inheren dari eksistensi fisiknya, padahal pada kenyataannya makna tersebut semata diciptakan lewat integrasinya ke dalam sistem makna. 
Seperti yang dikatakan Marx, fetisisme ini adalah sebuah fenomena yang diciptakan manusia. Dalam kasus ini, fetisisme komoditas muncul ketika Harry Potter diproduksi sebagai sebuah komoditas untuk dikonsumsi massal yang di dalamnya terkandung teks yang mengkomunikasikan berbagai relasi sosial (kelas, status, kondisi, peran, tingkat, prestise) yang beroperasi dalam konteks sosial. Marx, selanjutnya menggunakan istilah mistifikasi (mystification) untuk menjelaskan tampilan palsu (false apperance) atau makna palsu (false meaning) pada sebuah produk yang sebenarnya sudah mempunyai makna tertentu (yang otentik) di dalam masyarakat.

Bagi orang-orang yang merupakan Harry Potter mania, Hogwarts merupakan sekolah tujuan favorit mereka, mereka ingin mengenakan seragam sekolah Hogwarts serta menenteng tongkat sihir, naik sapu terbang, dan bermain Quidditch. Peron $3 / 4$ di stasiun bawah tanah kota London adalah tempat tujuan untuk menaiki kereta yang membawa mereka masuk ke dunia Harry. Mereka ingin bisa melafalkan berbagai mantra sihir dan berdis-apparate ke belahan dunia manapun yang mereka inginkan. Mereka ingin memiliki keberanian yang dimiliki Harry, kesetiaan Ron, atau kepandaian Hermione. Mereka ingin terlibat dalam dunia magic Harry yang penuh perjuangan untuk melawan dia-yang-namanya-tidak-bolehdisebut, Lord Voldemort.

Inilah gambaran masyarakat yang tergila-gila pada produk industri budaya Harry Potter dan memuja-muja segala bentuk komoditas yang ditawarkannya. Bagi mereka, Harry Potter adalah pahlawan kehidupan yang menyelamatkan dunia dari pengaruh sihir hitam Voldemort. Dalam sebuah artikel berjudul "Be a True Harry Potter Fan",iv, terdapat 11 langkah yang harus dilakukan dalam ritual konsumerisme komoditas magic ini: (1) Membaca semua buku Harry Potter (17) berkali-kali, dengan tidak meminjam melainkan harus membeli semua seri; (2) Membeli seluruh sekuel film Harry Potter; (3) Mengingat setiap detail dalam buku/film favorit; (4) Melibatkan diri dalam kelompok fansite; (5) Mengingat semua nama dari setiap karakter yang ada; (6) Berbagi cinta Harry Potter; (7) Mengirim surat/email ke aktor/aktris film Harry Potter; (8) Mencari informasi sebanyak-banyaknya yang berkaitan dengan Harry Potter; (9) Mengoleksi semua merchandise Harry Potter; (10) Memperbandingkan buku dengan film; dan (11) Mengimitasi karakter favorit yang disukai dalam Harry Potter.

Ritual konsumsi seperti yang dijelaskan di atas hanya satu di antara sekian banyak cara yang bisa digunakan untuk mengkonsumsi Harry Potter. Lahirnya berbagai kelompok fandom Harry Potter di berbagai belahan dunia adalah salah satu bentuk perayaan terhadap konsumerisme dunia sihir Harry Potter. Ragam praktek konsumsi komoditas semacam inilah yang dikaitkan dengan kapitalisme dan komodifikasi, yang selanjutnya memunculkan perdebatan antara Marx (1850), Adorno (1940) dan Althusser (1970), di mana dalam komoditas tersebut melekat makna ideologis yang melayani kepentingan kapitalisme (...that commodities carry embedded ideological meanings that serve the interests of capitalism and which are taken on board by consumers through the very act of consumption $)^{\mathrm{v}}$. Konsumsi pada dasarnya merupakan wujud kebebasan pribadi individu. Namun ketika praktek konsumsi dikontrol oleh kapitalisme, maka segala bentuk kegiatan konsumsi pada ujungnya akan diakhiri dengan kepentingan kapital. Atas dasar kepentingan kapital inilah, industri budaya (Harry Potter) memasukkan berbagai nilainilai ideologis dalam produk komoditasnya yang ditujukan untuk mengontrol perilaku konsumen menjadi sejalan dengan kepentingan kapitalis (AOL-Time Warner). 
Marxis memperlihatkan masyarakat kapitalis sebagai salah satu kelas dominan; media dilihat sebagai bagian dari wilayah ideologis yang di dalamnya berbagai pandangan kelas saling berlawanan, walaupun berada dalam konteks dominasi kelas-kelas tertentu; kontrol utama sangat terkonsentrasi pada monopoli modal; para profesional media, ketika menikmati ilusi otonomi, disosialisasikan dan diinternalisasikan ke dalam norma budaya dominan; media diterima sebagai sebuah keutuhan, yang menempatkan kembali pemikiran intepretif sesuai dengan minat kelas dominan, dan khalayak media.

Sang kapitalis, AOL-Time Warner, sebuah konglomerat media global telah mentransformasikan ketujuh buku seri Hary Potter ke dalam komoditas tanda yang diproduksi terus-menerus secara komersial (a commodity-sign reproduced endlessly across the commercial landscap $)^{\mathrm{vi}}$, yang di dalamnya terkandung ragam komoditas yang menyembunyikan berbagai nilai-nilai ideologis. Berikut merupakan uraian mengenai beberapa agenda tersembunyi media dalam industri budaya Harry Potter yang berwujud ideologi-ideologi yang pada akhirnya ditujukan untuk kepentingan kapitalis, di mana posisi ideologis merupakan fungsi dari posisi kelas, dan ideologi dominan dalam masyarakat merupakan ideologi dari kelas dominan.

\subsection{The Consumption of Class and Power Relation}

Analisis mengenai buku-buku Harry Potter memunculkan berbagai argumen, salah satunya adalah bagaimana isu mengenai kelas dan kekuasaan direpresentasikan dalam teks ciptaan Rowling ini. Harry Potter menawarkan konsumsi relasi kelas dan kekuasaan yang sangat kuat di sepanjang kisah hidupnya, relasi antara dua dunia yang dibedakan atas the nonmagical ("muggle") world dan the magical wizarding world (pure blood vs mud blood). Dua dunia ini sarat dengan diferensiasi kelas dan kekuasaan yang terstrukturkan di dalam dunia sihir Harry Potter.

Oxford English Dictionary (OED), ketika memasukkan istilah "muggle" ke dalam OED di tahun 2003, mendefinisikan muggle sebagai "in the fiction of J.K. Rowling: a person who possesses no magical powers. Hence in allusive and extended uses: a person who lacks a particular skill or skills, or who is regarded as inferior in some way". Muggle adalah orang yang tidak mempunyai kekuatan sihir, atau di dalam istilah yang lebih umum, muggle diartikan sebagai orang yang memiliki kekurangan dalam keahlian tertentu atau bahkan tidak memiliki keahlian.

Relasi kelas yang terdapat di kisah Harry Potter, menjelaskan bahwa kelas muggle merupakan kelas inferior yang dalam prakteknya selalu ditindas dan dimanfaatkan oleh kelas penyihir. Inferioritas kelas muggle terlihat sangat jelas ketika di dalam dunia Harry Potter terdapat keturunan campuran penyihir dan muggle, yang sering disebut dalam istilah "mud blood" (darah kotor). Sosok Harry Potter sendiri, serta salah satu teman terbaiknya, Hermione, adalah penyihir yang merupakan keturunan muggle. Keberadaan kelompok kelas mud blood inilah yang mengawali konflik kelas dalam kisah Harry Potter ini, di mana para penyihir yang merupakan darah asli tidak menerima keberadaaan penyihir darah campuran karena dianggap mengotori dunia sihir.

Relasi kelas dalam dunia sihir Harry Potter, merupakan representasi dari relasi kelas yang terjadi di dunia nyata. Dunia sihir Harry Potter, secara strategis mengeksploitasi keberadaan relasi kelas ini sejak awal kisah ini dilahirkan, mulai dari buku pertama hingga buku ketujuh. Harry pernah mengalami ketidakadilan terkait isu relasi kelas ketika pada masa kecil kehidupannya di rumah pamannya, Harry hanya diberikan sebuah ruangan kecil dan pengap di bawah tangga di rumah itu dan tidak diperbolehkan keluar karena 
dianggap sebagai anak yang membawa aib bagi keluarga pamannya. Kisah eksploitasi lain yang dialami Harry dapat diringkas sebagai berikut: "Harry Potter, adalah the alive child, satu-satunya anak yang mampu bertahan hidup ketika sihir hitam Voldemort membunuh kedua orangtuanya. Pembunuhan itu didasarkan pada rasa dengki Voldemort terhadap keturunan darah kotor keluarga Harry serta obsesinya untuk mencari kekuasaan di dunia sihir". Kisah konflik mengenai relasi kelas dan kekuasaan ini terus berlanjut dalam setiap seri bukunya, menggambarkan bagaimana Voldemort berulang kali mencoba untuk membunuh Harry karena keberadaan Harry dianggap sebagai ancaman baginya dalam perebutan kekuasaan.

Komodifikasi relasi kelas dan kekuasaan dalam dunia Harry Potter ini, mengubahnya menjadi objek yang dikonsumsi oleh para pembaca dan penonton kisah ini. Waetjen dan Gibson (2007) mendeskripsikan bagaimana AOL-Timer Warner, selaku produsen film Harry Potter, mengeksploitasi berbagai diskursus mengenai kelas, menjadikannya sebagai komoditas yang dikonsumsi dan dipuja oleh masyarakat, seperti yang dijelaskan dalam kalimatkalimat berikut:

... In the end, we argue that although her novels can be read as a politically engaged critique of class inequality, crass materialism, and racial discrimination ... In short, Rowling's portrayal of Harry as a gadget-loving hero, when combined with her vision of an economic system seemingly devoid of labor exploitation and commodity fetishism, could be read as a fullthroated celebration of guiltfree consumption. And, indeed, we argue that it is precisely this reading that AOL Time Warner has "activated" in its commercial appropriation and amplification of the Harry

Potter universe. (Waetjen dan

Gibson, 2007:5)

Berdasarkan uraian di atas, Waetjen dan Gibson menyebutkan bahwa media (dalam hal ini AOL Time Warner) berfungsi sebagai amplifier yang menyebarluaskan pengaruh dunia Harry Potter (Harry Potter universe) ke dalam dunia nyata yang pada hakikatnya memiliki kesamaan dengan dunia Harry, yaitu sarat dengan diskursus mengenai ketidakadilan, materialisme, dan diskriminasi. Pada dasarnya, Harry Potter dapat dilihat sebagai sebuah karya sastra yang mengandung kritik terhadap praktek relasi kelas dan kekuaasaan yang ada di masyarakat. "In short, in her Potter series, Rowling offers a subtle critique of class inequality pleasingly wrapped in a fantasy fairy tale" (Waetjen dan Gibson, 2007:10). Rowling mengisahkan berbagai kritik terhadap ketidakadilan/ketidaksamaan dalam kemasan kisah fairy tale, seolah sebuah kisah dongeng yang menghibur bagi pembacanya yang terutama ditujukan untuk anak-anak. Namun kritik ini menjadi bias ketika AOL Time Warner mendapatkan hak atas produksi film dan merchandise Harry Potter. AOL Time Warner tidak lagi merepresentasikannya sebagai sebuah kritik terhadap relasi kelas dan kekuasaan melainkan berubah menjadi sebuah komoditas yang di dalam teks-nya terdapat permainan simbol-simbol relasi yang semakin dikukuhkan keberadaannya di dunia ini. Kritik tersebut tidak lagi berupa fairy tale, namun dikomersialkan menjadi komoditas yang penuh dengan kepentingan ideologis sang kapital. Harry Potter menjadi sebuah teks yang kaya akan ideologi-ideologi yang mengukuhkan keberadaan kelas penguasa dan kelas inferior, apa pun bentuknya. Ketika dikaitkan dengan AOL-TimeWarner, maka kita akan menemukan bahwa TimeWarner difungsikan sebagai kelas penguasa, yang memanfaatkan inferioritas 
masyarakat untuk dijadikan konsumen terhadap segala bentuk komoditas yang ditawarkannya.

\subsection{Pers, and The Consumption of News}

Rowling, melalui rangkaian novelnya, mengisahkan salah satu angle cerita tentang bagaimana pekerja pers dalam dunia sihir Harry Potter merupakan sosok yang sangat kontroversial. J.K. Rowling memang memiliki kemampuan dalam menghidupkan karakter. Rita Skeeter, salah satu karakter yang kuat dan kontroversial dalam dunia Harry. Rita Skeeter merupakan sosok wartawan yang bekerja pada harian Daily Prophet. Sebagai seorang wartawan, Sketeer paling suka menjual cerita-cerita sensasional terutama mengenai Harry Potter dan sang kepala sekolah sihir Hogwarts, Dumbledore.

Rita mulai muncul dalam sejak buku keempat, Harry Potter and the Goblet of Fire. Sosok antagonis ini merupakan penyihir berdarah murni yang suka mereka-reka cerita tentang Harry dengan tujuan menjual sensasionalisme. Sekali lagi, ini adalah bentuk kritik terhadap praktek jurnalisme saat ini yang tidak lagi memenuhi kaidah/etika jurnalisme, namun kritik ini ditransformasikan sebagai sebuah komoditas untuk diperjualbelikan kepada masyarakat yang mengkonsumsinya.

\subsection{The Consumption of Death, the Paradox of God}

Hampir sebagian besar kisah Harry Potter didominasi oleh cerita-cerita tentang kematian. Mulai dari kisah kematian ayah dan ibu Harry, diikuti dengan kematian ayah baptisnya Sirius Black, kematian makhluk peri rumah kesayangannya, kematian professor Snape, kematian Dumbledore, hingga akhirnya berujung pada kematian Voldemort. Rowling juga menyisipkan berbagai karakter dan objekobjek yang berbau kematian, seperti pelahap maut, dan mantra sakti untuk membunuh orang yaitu "avada kedavra".
Dari rangkaian kisah kematian tersebut, yang paling menarik adalah kematian Harry Potter. Harry, dalam buku ke tujuh yaitu Harry Potter and The Deathly Hallows (Harry Potter dan Relikui Kematian) digambarkan mengalami kematian namun kemudian hidup kembali. Kisah kematian ini dipercayai sebagai kisah yang diadopsi dari kematian Tuhan dalam Kitab Injil, seperti yang dikisahkan juga dalam kisah The Chronicle of Narnia. Perdebatan yang muncul kemudian dari cerita adopsi ini adalah mengapa sosok Harry Potter dianggap sama derajatnya dengan sosok Tuhan.

Di dalam kultur kontemporer, Tuhan kemudian tumbuh menjadi paradoks. Implikasi yang muncul kemudian adalah pemahaman akan Tuhan itu sendiri berubah menjadi ideologi yang kemudian akan berbenturan dengan ideologi lain. Kultur kontemporer memperlakukan Tuhan sebatas memperlakukan sejarah di berbagai kitab suci (Audivax, 2006: 78, 85). Paradoks tentang Tuhan banyak muncul dalam kisah Harry terutama di dalam buku terakhirnya, Harry Potter dan Relikui Kematian. Dalam sebuah setting dijelaskan bahwa Dumbledore memberikan warisan kepada Harry Potter berupa Snitch (yaitu salah satu bola dalam permainan sihir Quidditch) dengan sebuah petunjuk: "Aku membuka pada penutup" (I open at the Close). Pemahaman mengenai kalimat ini hampir sama jika diintepretasikan dalam kalimat I am the Alpha dan the Omega (Akulah yang awal dan yang akhir), sebuah pernyataan ke-Tuhan-an dalam agama Kristen.

Dalam industri budaya, ketika sosok Tuhan diubah menjadi teks media, permainan tanda dan simbol yang terdapat di dalamnya menjadi sebuah permainan tontonan kematian Tuhan yang ditunjukkan dalam bentuk mitologi. Mitologi adalah salah satu artefak kultural yang menjelaskan "Tuhan" bisa hidup dan juga bisa mati. Dalam mitologi kontemporer Harry Potter, terkandung 
pesan-pesan mitologis seperti yang disampaikan dalam Harry Potter and The Order of Phoenix:

"Karena ini kamar yang hanya bisa dimasuki ... kalau orang benar-benar membutuhkannya. Kadang-kadang kamar ini ada dan kadang-kadang tidak, tapi kalau muncul, kamar ini selalu dilengkapi dengan apa yang dibutuhkan pencarinya ... kebanyakan orang tak sengaja menemukannya ketika mereka membutuhkannya ... tapi mereka sering kali tak pernah menemukannya lagi, karena mereka tak tahu kamar itu selalu di sana". Pesan tersebut terdengar menyerupai 'doa'. Manusia memang sering kali tak pernah menemukan lagi kekuatan doa, karena mereka tak tahu kamar (ruang untuk berdoa) itu selalu di sana (bersama manusia). (Audivax, 2006:88)

Sosok Tuhan juga menimbulkan pertanyaan besar ketika Rowling menggunakan istilah "Lord" (Tuhan) untuk menamai sang penyihir hitam, Voldemort-Lord Voldermort. Rowling menciptakan karakter ini sebagai sosok kelam yang sangat terobsesi dengan kekuasaan dan kehidupan abadi. Anehnya, dalam kisah ini nama Lord Voldemort merupakan nama terlarang yang tidak boleh disebut dengan sembarangan. Rowling menambahkan istilah "dia-yangnamanya-tidak-boleh-disebut", "kau tahu siapa", "pangeran kegelapan". Tuhan, dalam hal ini digambarkan sebagai sebuah konsep yang penuh dengan citra kegelapan yang olehnya ketakutan disebarluaskan.

Seiring perdebatan tentang konsep Tuhan, Harry Potter menunjukkan sebuah inkonsistensi mengenai agama. Harry yang pada dasarnya merupakan seorang penyihir, tidak dikaitkan dengan keberadaan agama tertentu, namun di beberapa setting Harry Potter terkesan menunjukkan keterkaitan dengan agama Kristen yang terwujud dalam perayaan Natal yang diadakan di sekolah sihir Hogwarts. Meskipun demikian, ritual natal yang terdapat dalam Harry Potter tidak persis sama dengan yang terdapat di agama Kristen. Tampaknya, Rowling melalui teks Harry Potternya, hanya sekedar meminjam tradisi agama tertentu untuk dijadikan komoditas konsumsi dalam industri budaya Harry Potter.

\subsection{The Consumption of Myth}

Salah satu kenangan membaca karya-karya J.K. Rowling adalah menemukan beberapa referensi mengasyikkan dari sejarah, legenda, dan literatur yang disembunyikannya dalam buku-bukunya. Contohnya, Sphinx di dalam maze pada Turnamen Triwizard menanyakan sphinx dalam mitologi Mesir Kuno. Anjing peliharaan Hagrid, Fluffy, sebenarnya makhluk terkenal dari mitologi Yunani, Cerberus. "Durmstrang", nama sekolah sihir yang hanya menerima murid penyihir berdarah murni dan dicurigai berhubungan dengan Lord Voldemort, berasal dari gaya artistik Jerman yang disebut Sturm und Drang, yang merupakan favorit Nazi Jerman. Rowling juga menyembunyikan petunjuk-petunjuk mengasyikkan dalam nama-nama yang dipilihnya. Draco, mendapatkan namanya dari kata Latin untuk 'naga' atau 'ular'. Phoenix peliharaan Dumbledore, Fawkes, namanya diambil dari tokoh sejarah yang terkait dengan api unggun, seperti phoenix yang katanya bisa hidup kembali dari api. Penjaga sekolah Hogwarts, Argus Filch, diambil dari Argus, tokoh mitologi Yunani, penjaga yang memiliki seribu mata di tubuhnya" (Colbert, 2006: 15-16).

Rowling memang merupakan seorang arsitek. Ia mampu menciptakan sebuah dunia sihir yang memiliki citra yang berbeda dari dunia sihir yang dikenal selama ini. Dalam dunia ciptaannya, Rowling menyisipkan berbagai potonganpotongan sejarah berupa penggalan- 
penggalan mitologi yang kononnya telah ada sejak ratusan dan bahkan ribuan tahun sejak sebelum Harry Potter diterbitkan. Dengan melekatkan berbagai potongan sejarah dan mitologi seperti yang disebutkan Colbert di atas, Rowling membuat perpaduan antara dunia sihir dan dunia nyata, antara muggle dan wizard.

Dunia sihir dan dunia nyata adalah dua dunia yang berbeda, bahkan ada yang menganggap sihir hanya sebatas imajiner manusia. Hadirnya produk budaya kontemporer Harry Potter kini menjadikan dua dunia itu menjadi satu, mengaburkan batas-batas yang selama ini ada dan mencampuradukkan realitas yang terkandung di dalamnya.

\section{PENUTUP}

Kehadiran industri budaya yang diperkenalkan oleh Adorno dan Horkheimer, merupakan sebuah peluang kebebasan bagi produksi produk-produk kultural, terutama ketika media kini telah memasuki era digital yang dapat digunakan sebagai alat ekspansi produk industri budaya tersebut. Ketika kisah tentang sang penyihir Harry Potter bertransformasi dari teks dalam buku menjadi teks dalam budaya populer berbentuk film, segala sesuatu yang terdapat di dalamnya mengalami reproduksi. Teks, yang di dalamnya melekat simbol dan tanda, dikomodifikasikan menjadi komoditas kontemporer yang merupakan penawaran terhadap adanya

\section{Daftar Pustaka}

Adorno, Theodor dan Max Horkheimer. "The Culture Industry: Enlightment as Mass Deception". Dalam Simon During (Ed). 1993. The Cultural Studies Reader, 2nd edition. London: Routledge

Audivax. 2006. "Raiders of The Lost God". Dalam Alfathri Adlin. Spiritualitas dan Realitas Kebudayaan Kontemporer (hal.7791). Yogyakarta: Jalasutra konsumsi massal. Kisah, cerita, sejarah, setting, karakter - keseluruhan dunia Harry Potter yang terdapat di dalam novel karya J.K.Rowling ini berpindah medium menjadi sebuah dunia tiga dimensi yang diproduksi oleh AOL-TimeWarner.

Media adalah institusi ideologis, yang bergerak untuk kepentingan ideologi sang kapitalis dan berjuang untuk menciptakan masyarakat konsumen yang mengkonsumsi komoditas hasil produksi media. Dalam hal ini, ketika teks Harry Potter bertransformasi, berbagai kepentingan ideologis yang tersembunyi di baliknya menjadi terlihat lebih nyata. Namun kekaguman akan dunia Harry Potter yang kaya akan permainan sihir yang tidak ditemukan dalam dunia real, menjadikannya sebagai sebuah barang konsumsi massa, terlepas dari berbagai kontroversi yang muncul terkait ideologi tersembunyi yang diagendakannya. Meskipun demikian, agenda tersembunyi media tetap berlanjut. Di sini, media sebagai produsen industri budaya berfungsi sebagai alat ideologis pencipta kesadaran palsu yang seolah-olah takenfor-granted. Segala bentuk ideologi yang melekat dalam Harry Potter dianggap sebagai sebuah realitas yang nyata meskipun sebenarnya merupakan hasil produksi dan reproduksi yang dilakukan oleh kapitalis.

Barker, Chris. 2004. The Sage Dictionary of Cultural Studies. London: Sage Publications.

Colbert, David. 2006. The Magical Worlds of Harry Potter. Jakarta: Gramedia Pustaka Utama

Elliot, Anthony. 2009. Contemporary Social Theory: An Introduction. London: Routledge

Rowling, J.K. The Harry Potter Series (book 1-7)

Stokes, Janes. 2003. How to do Media and Cultural Studies. Yogyakarta: Bentang Pustaka 
Waetjen, Jarrod dan Timothy A. Gibson. 2007. Harry Potter and the Commodity Fetish: Activating Corporate Readings in the Journey from Text to Commercial Intertext.

i Akun twitter @HarryPotterings. Diakses

16 Februari 2012

ii Harry Potter and the Sorcerer's Stone (1997), Harry Potter and the Chamber of Secrets (1998), Harry Potter and the Prisoner of Azkaban (1999), Harry Potter and the Goblet of Fire (2000), Harry Potter and the Order of the Phoenix (2003), Harry Potter and the Half-Blood Prince (2005), Harry Potter and the Deathly Hallows (2007).

iii Harry Potter and the Sorcerer's Stone (2001), Harry Potter and the Chamber of Secrets (2002), Harry Potter and the Prisoner of Azkaban (2004), Harry Potter and the Goblet of Fire (2005), Harry Potter and the Order of the Phoenix (2007), Harry Potter and the Half-Blood Prince (2009), Harry Potter and the Deathly Hallows-Part One (2010), Harry Potter and the Deathly Hallows-Part Two (2011).

${ }^{\text {iv }}$ http://www.wikihow.com/Be-a-TrueHarry-Potter-Fan

${ }^{\vee}$ The Sage Dictionary of Cultural Studies (2004) hal. 33

${ }^{\text {vi }}$ Waetjen dan Gibson (2007) hal. 5
Dalam Communication and Critical/Cultural Studies Vol. 4, No. 1, March 2007, (hal 3-26). USA: Routledg 